\title{
Pengaruh Vitamin D terhadap Ekspresi COX-2, Kadar CAMP, Kadar Renin Darah dan Tekanan Darah Sistolik dalam Sistem Renin Angiotensin Aldosteron
}

\section{Effect of Vitamin D on the Expression of COX-2, levels of CAMP, Renin Blood Levels and Systolic Blood Pressure in Renin Angiotensin Aldosterone System}

\author{
Dessy Hermawan ${ }^{1}$, Sri Kadarsih $S^{2}$, Sunarti ${ }^{3}$, Indwiani Astuti ${ }^{4}$, Zainal Arifin $N A^{3}$ \\ ${ }^{1}$ Program Studi IImu Keperawatan Fakultas Kedokteran Universitas Malahayati Bandar Lampung \\ ${ }^{2}$ Laboratorium Fisiologi Fakultas Kedokteran Universitas Gadjah Mada Yogyakarta \\ ${ }^{3}$ Laboratorium Biokimia Fakultas Kedokteran Universitas Gadjah Mada Yogyakarta \\ ${ }^{4}$ Laboratorium Farmakologi Fakultas Kedokteran Universitas Gadjah Mada Yogyakarta
}

\begin{abstract}
ABSTRAK
Banyak penelitian yang melaporkan hubungan antara kadar vitamin D dalam darah dengan hipertensi, hanya saja mekanismenya dalam sistem renin angiotensin belum dapat dijelaskan dengan pasti. Hal ini yang menarik untuk mempelajari mekanisme aksi vitamin D dalam dalam pengaturan tekanan darah di sistem renin angiotensin aldosteron. Rancangan penelitian ini adalah eksperimen laboratorik dengan pre-post test group design, yang di bagi menjadi dua tahap. Tahap pertama untuk mempelajari pengaruh vitamin D terhadap ekspresi COX-2 di sel macula densa ginjal dan tahap kedua untuk mempelajari mekanisme aksi vitamin D dalam pengaturan tekanan darah. Hasil yang di dapat bahwa sasaran aksi vitamin $D$ pada sistem renin angiotensin aldosteron kemungkinan ada di dua bagian, yaitu ada yang di bagian up-stream cAMP dengan menekan ekspresi COX-2 di sel macula densa ginjal dan ada yang di bagian down-stream cAMP, yaitu dengan menekan langsung gen yang menyandi renin. Hal ini didukung dengan data bahwa tidak terjadinya akumulasi CAMP, peningkatan kadar renin dan TDS walaupun hewan coba telah diberi teofilin bersamaan dengan vitamin $D$.
\end{abstract}

Kata Kunci: CAMP, COX-2 dan tekanan darah sistolik, hipertensi, renin, vitamin D

\section{ABSTRACT}

Many studies report an association between vitamin D levels in the blood with hypertension, only the mechanism in the renin-angiotensin system can not be explained with certainty. It is interesting to study the mechanism of action of vitamin $D$ in the regulation of blood pressure in the renin-angiotensin-aldosterone system. The study design was a laboratoric experiment with pre-post test group design, which was divided into two stages. The first stage was to study the effect of vitamin D on the expression of COX-2 in the macula densa cells of kidney and the second stage to study the mechanism of action of vitamin $D$ in regulating blood pressure. The results showed that the target of action of vitamin $D$ on reninangiotensin-aldosterone axis probably in two parts, that is one up-stream of CAMP by suppressing the expression of COX-2 in cells of the macula densa of kidney and another one down-stream of CAMP, by supress rennin gene. This is supported by data that was no accumulation of CAMP, increased levels of renin and TDS the experimental animals were given theophylline co administered with vitamin $D$.

Keywords: CAMP and systolic blood pressure, hypertension, renin, vitamin D

Korespondensi: Dessy Hermawan. Program Studi IImu Keperawatan Fakultas Kedokteran Universitas Malahayati Bandar Lampung, JI. Pramuka No. 27, Kemiling, Kota Bandar Lampung, Lampung Tel. (0721)271114 Email: hermawan.dessy@gmail.com 


\section{PENDAHULUAN}

Hipertensi adalah penyakit yang diderita $30 \%$ dari populasi orang dewasa di Amerika (1), dan angka kejadiannya terus meningkat. Hanya saya kebanyakan dari penderita hipertensi tidak menyadari akan sakit yang dideritanya. Data di Amerika menunjukkan ada 9,2\% orang terdiagnosis hipertensi pada orang yang datang ke dokter/tenaga kesehatan tanpa keluhan hipertensi (2). Padahal jika tidak di kontrol dengan baik, hipertensi dapat menimbulkan komplikasi berupa penyakit kardivaskuler, jantung koroner, gagal jantung, gagal ginjal, kelahiran prematur hingga kematian. Disimpulkan bahwa mengontrol tekanan darah adalah cara terbaik untuk melindungi ginjal dan jantung dari kerusakan (3).

Akhir-akhir ini banyak penelitian yang melaporkan bahwa ada hubungan antara vitamin D dengan kejadian hipertensi (4,5). Pada tahun 1997 dilaporkan bahwa semakin jauh manusia tinggal dari garis khatulistiwa, maka semakin cenderung mereka mengalami peningkatan tekanan darah (6). Kondisi ini diduga karena semakin jauh dari khatulistiwa maka tubuhnya semakin kekurangan vitamin D. Hal ini terjadi akibat tubuh kekurangan paparan matahari (ultraviolet) sehingga kulit tidak mampu melakukan biosintesis provitamin D menjadi vitamin D. Penelitian tersebut didukung oleh sejumlah penelitian sejenis yang membuktikan bahwa ditemukan kadar vitamin D yang rendah pada penderita hipertensi $(7,8)$. Bahkan penelitian melaporkan bahwa pemberian vitamin $D$ dapat menurunkan produksi renin dengan menekan langsung produksi renin di ginjal, hanya saja mekanismenya belum dapat diterangkan dengan pasti. Diduga vitamin D langsung menekan ekspresi gen yang mengode renin dengan cara menghambat kerja enzim RNA Polimerase II (9). Jika renin dapat ditekan produksinya oleh vitamin D, maka sistem renin angiotensin-aldosteron tidak teraktifasi sehingga tidak akan terjadi peningkatan tekanan darah. Dari paparan ini menjelaskan bahwa sasaran kerja dari vitamin $\mathrm{D}$ dalam sistem renin angiotensin aldosteron ada di bagian sesudah cAMP $(4,5,9)$.

Peran vitamin D juga dilaporkan ada pada sel kanker, pada bagian ini vitamin $D$ juga mampu menghambat perkembangan sel kanker dengan menekan ekspresi COX2, menghambat kerja reseptor prostaglandin dan mengaktifkan enzim 15-Prostaglandin Dehidogenase (15PDGH), yang kesemuanya terjadi di bagian up-stream CAMP (10). Karena mekanisme kerja vitamin D, dalam sistem pengaturan tekanan darah dan sel kanker memiliki banyak kesamaan, maka menimbulkan sebuah dugaan/hipotesis, bahwa dalam sistem pengaturan tekanan darah, vitamin D tidak hanya menekan proses transkripsi gen renin saja, tetapi seperti yang dilaporkan $(4,5)$, juga mampu menghambat ekspresi COX-2 di sel macula densa ginjal.

Jika vitamin D mampu menghambat ekspresi COX-2, maka proses pengubahan asam arakhidonat menjadi prostaglandin tidak terjadi, sehingga tidak ada prostaglandin yang akan mengaktifkan Cyclic adenosine monophosphate (cAMP) di sel juxtaglomerular dan hasil akhirnya tidak akan ada produksi renin. Penulis juga tertarik untuk mencari sasaran aksi dari vitamin D di sistem renin angiotensin aldosteron, sehingga akan mencoba memberikan vitamin $\mathrm{D}$ bersama dengan teofilin, suatu bahan yang telah terbukti mampu mengakumulasi cAMP, jika ternyata pemberian vitamin $\mathrm{D}$ bersama dengan teofilin mampu menekan peningkatan cAMP sel ginjal, maka dapat dipastikan sasaran aksi vitamin D juga ada di bagian up-stream cAMP.

\section{METODE}

Penelitian ini adalah penelitian eksperimen laboratorik sederhana dengan rancangan pre-post-test group design yang mempelajari peranan vitamin $D$ dalam sistem renin angiotensi aldosteron. Penelitian ini di bagi menjadi dua tahap, tahap yang pertama adalah untuk mempelajari pengaruh pemberian vitamin $D$ terhadap ekspresi COX-2 di sel makula densa ginjal, sedangkan tahap yang kedua adalah untuk mempelajari sasaran aksi vitamin $D$ di bagian up-stream cAMP dalam sistem renin angiotensin aldosteron.

\section{Tahap Pertama}

Tahap ini adalah untuk melihat pengaruh pemberian vitamin D terhadap ekspresi COX-2 di sel macula densa ginjal hewan coba. Subjek dalam penelitian tahap pertama adalah 25 ekor tikus putih (Rattus norvegicus) jantan usia 8 minggu yang diperoleh dari Laboratorium Penelitian dan Pengujian Terpadu Universitas Gadjah Mada (LPPT UGM) Yogyakarta. Pemeliharaan dan perlakuan serta pengukuran tekanan darah sistolik hewan coba dilakukan di laboratorium hewan coba Pusat Antar Universitas (PAU) UGM Yogyakarta, sedangkan pengukuran ekspresi COX-2 dengan menggunakan metode imunohistokimia (IHK) dilakukan di laboratorium PA FK UGM Yogyakarta.

Subjek dibagi menjadi 5 kelompok perlakukan (K1-K5) yang masing-masing akan mengalami perlakuan berupa penghilangan asupan vitamin D selama 7 hari dan pemberian kembali asupan vitamin D selama 4 hari, perlakuan didasarkan laporan penelitian sebelumnya yang melaporkan 7 hari penghilangan asupan vitamin D sudah mampu menurunkan kadar vitamin $\mathrm{D}$ dalam darah dan mampu meningkatan tekanan darah sistolik (TDS) secara bermakna, sedangkan 4 hari pemberian vitamin $D$ juga telah mampu meningkatan kembali kadar vitamin D dalam darah dan menurunkan TDS seperti semula (11). Perlakuan tahap pertama secara lengkap disajikan pada Tabel 1.

Tabel 1. Perlakuan untuk masing-masing kelompok perlakuan tahap pertama

\begin{tabular}{|c|c|c|}
\hline Kelompok & $\begin{array}{c}\text { Penghilangan } \\
\text { asupan Vit D } \\
\text { (diletakkan dalam } \\
\text { kandang gelap } \\
\text { terus \& diberi } \\
\text { pakan tanpa vit D) }\end{array}$ & $\begin{array}{c}\text { Pemberian asupan Kembali Vit D } \\
\text { (diletakkan dalam kandang terang- } \\
\text { gelap siklus } 12 \text { jam \& diberi pakan } \\
\text { standar) }\end{array}$ \\
\hline $\begin{array}{c}\text { K1 } \\
\text { (kontrol -) }\end{array}$ & 11 hari & - \\
\hline $\mathrm{K} 2$ & 7 hari & $\begin{array}{l}\text { Diberi asupan vitamin } D \text { peroral } \\
\text { sebanyak } 0,125 \quad \mu \mathrm{g} / \mathrm{kgBB} / \text { hari } \\
\text { selama } 4 \text { hari }(1 / 2 \text { dosis })\end{array}$ \\
\hline K3 & 7 hari & $\begin{array}{l}\text { Diberi asupan vitamin D peroral } \\
\text { sebanyak } 0,25 \quad \mu \mathrm{g} / \mathrm{kgBB} / \mathrm{hari} \\
\text { selama } 4 \text { hari (Dosis normal) }\end{array}$ \\
\hline K4 & 7 hari & $\begin{array}{l}\text { Diberi asupan vitamin } D \text { peroral } \\
\text { sebanyak } 0,5 \mu \mathrm{g} / \mathrm{kgBB} / \text { hari selama } \\
4 \text { hari ( } 2 \text { kali dosis) }\end{array}$ \\
\hline $\begin{array}{c}\text { K5 } \\
(\text { Kontrol +) }\end{array}$ & $\begin{array}{l}11 \text { hari dan di beri } \\
\text { indomethacin } 3 \\
\mathrm{mg} / \mathrm{Kg} \mathrm{BB} / \mathrm{hari} \\
\text { selama } 4 \text { hari. }\end{array}$ & - \\
\hline
\end{tabular}


Untuk mempelajari pengaruh asupan vitamin D terhadap penurunan ekspresi COX-2 di sel macula densa ginjal dan penurunan tekanan darah sistolik, maka dilakukan pengukuran tekanan darah sebelum dan sesudah perlakuan, yaitu pada hari ke 7 dan hari ke 11. Tekanan darah diukur dengan menggunakan alat pengukur tekanan darah yang ada di laboratorium PAU UGM. Arteri yang digunakan untuk pengukur tekanan darah adalah arteri ekor tikus dan hanya tekanan darah sistolik saja yang dapat terbaca oleh alat tersebut.

Kemudian untuk mempelajari pengaruh pemberian kembali asupan vitamin D terhadap penurunan ekspresi COX-2 di sel macula densa ginjal, maka pada hari ke 11, hewan coba dikorbankan kemudian diambil ginjalnya dan difiksasi dengan larutan dapar formalin dan segera di buat preparat histologinya. Pengukuran persentasi sel macula yang terekspresi COX-2 adalah dengan menghitung ratarata sel macula densa yang mengekspresikan COX-2 dari 10 lapang pandang/slidenya. Pembuatan dan pembacaan preparat histology dengan metode imunohistokimia dilakukan di laboratorium Patologi Anatomi (PA) FK UGM Yogyakarta. Khusus untuk kelompok K5 pada hari ke 8 hingga ke 11 diberi indometahacin 3mg/BB/hari, kelompok ini merupakan kelompok pembanding (kontrol positif), karena diketahui bahwa indometahacin merupakan penghambat kuat untuk COX-2.

\section{Tahap Kedua}

Pada tahap kedua peneliti menggunakan 35 ekor tikus jantan dengan berat rata-rata 200 gram yang yang berasal dari unit Pra-Klinik LPPT-UGM Yogyakarta. Pada tahap kedua ini, peneliti memberikan tambahan teofilin peroral dengan tujuan untuk menciptakan akumulasi cAMP, sehingga jika nantinya vitamin $D$ tetap mampu menurunkan kadar cAMP padahal telah diberi teofilin, maka menunjukkan bahwa penghambatan vitamin $\mathrm{D}$ ada dibagian sebelum cAMP.

Pada penelitian ini, pengukuran kadar cAMP sel ginjal dan pengukuran kadar renin darah dengan metode ELISA yang dilakukan di laboratorium Biokimia FK UGM Yogyakarta, sedangkan pemeriksaan TDS \& pemeliharaan hewan coba dilakukan di laboratorium PAU UGM Yogyakarta. Pada pengukuran kadar CAMP sel ginjal, pada hari ke 11, hewan coba dikorbankan dan diambil ginjalnya. Kemudian ginjal segar tersebut dimasukkan ke dalam nitrogen cair untuk dibekukan dan kemudian dihaluskan. Setelah nitogen cair menguap, masukkan ke dalam $0,1 \mathrm{M} \mathrm{HCl}$ dengan perbandingan 0,1 gram jaringan ke dicampur dengan $1 \mathrm{~mL}$ $0,1 \mathrm{M} \mathrm{HCl}$. Kemudian disentifugasi sekitar 10 menit $(\geq 600 \mathrm{x}$ g). Supernatan yang didapat, selanjutnya dapat diencerkan dalam $0,1 \mathrm{M} \mathrm{HCl}$ yang disediakan dan langsung dapat dilakukan langkah-langkah pengukuran kadar cAMP dengan metode ELISA pada jaringan ginjal yang telah lancur dengan menggunakan kit elisa buatan Enzo Life Science.

Pada pengukuran kadar renin darah dilakukan kegiatan sebagai berikut plasma diambil/dikumpulkan dan digunakan EDTA, atau heparin sebagai antikoagulan. Setelah disentrifugasi selama 15 menit pada $1000 \mathrm{~g}$ dalam waktu 30 menit, segara dilakukan pengukuran kadar renin menggunakan metode kit ELISA (Cusabio).

Perbedaan tiap kelompok sebelum dan sesudah perlakuan diuji statistik dengan uji $t$ dependent, sedangkan untuk melihat pengaruh perlakuan pada semua kelompok perlakuan, diuji dengan uji Anova dilanjutkan dengan posthoc test: LSD.

Tabel 2. Perlakuan untuk masing-masing kelompok perlakuan tahap kedua

\begin{tabular}{|c|c|c|}
\hline Kelompok & Perlakuan 7 hari pertama & Perlakuan 4 hari terakhir \\
\hline KGG & $\begin{array}{l}\text { Diletakkan dalam kandang gelap \& diberi } \\
\text { pakan tanpa vitamin D selama } 7 \text { hari }\end{array}$ & $\begin{array}{l}\text { Tetap diletakkan dalam kandang gelap \& diberi pakan tanpa } \\
\text { vitamin D selama } 4 \text { hari. }\end{array}$ \\
\hline $\mathrm{KGG}+\mathrm{Te}$ & $\begin{array}{l}\text { Diletakkan dalam kandang gelap \& diberi pakan } \\
\text { tanpa vitamin D selama } 7 \text { hari }\end{array}$ & $\begin{array}{l}\text { Tetap diletakkan dalam kandang gelap \&amp; diberi pakan tanpa } \\
\text { vitamin D selama } 4 \text { hari dan pada hari terakhir diberi tambahanteofilin } \\
25 \mathrm{mg} / \mathrm{kgBB} \text {. }\end{array}$ \\
\hline $\mathrm{KGT+D1}$ & $\begin{array}{l}\text { Diletakkan dalam kandang gelap \& diberi pakan } \\
\text { tanpa vitamin D selama } 7 \text { hari }\end{array}$ & $\begin{array}{l}\text { Diletakkan kembali dalam kandang terang dan diberi pakan standar } \\
\text { serta diberi asupan vitamin } D \text { peroral sebanyak } 0,25 \mu \mathrm{g} / \mathrm{kgBB} / \mathrm{hari} \\
\text { selama } 4 \text { hari }\end{array}$ \\
\hline $\mathrm{KGT}+\mathrm{D}_{1 / 2}+\mathrm{Te}$ & $\begin{array}{l}\text { Diletakkan dalam kandang gelap \& diberi pakan } \\
\text { tanpa vitamin D selama } 7 \text { hari }\end{array}$ & $\begin{array}{l}\text { Diletakkan kembali dalam kandang terang dan diberi pakan standar } \\
\text { serta diberi asupan vitamin } D \text { peroral sebanyak } 0,125 \mu \mathrm{g} / \mathrm{kgBB} / \mathrm{hari} \\
\text { selama } 4 \text { hari. Pada hari terakhir diberi tambahan teofilin } 25 \mathrm{mg} / \mathrm{BB} \text {. }\end{array}$ \\
\hline $\mathrm{KGT}+\mathrm{D} 1+\mathrm{Te}$ & $\begin{array}{l}\text { Diletakkan dalam kandang gelap \& diberi pakan } \\
\text { tanpa vitamin D selama } 7 \text { hari }\end{array}$ & $\begin{array}{l}\text { Diletakkan kembali dalam kandang terang dan diberi pakan standar } \\
\text { serta diberi asupan vitamin } D \text { peroral sebanyak } 0,25 \mu \mathrm{g} / \mathrm{kgBB} / \mathrm{hari} \\
\text { selama } 4 \text { hari. Pada hari terakhir diberi tambahan teofilin } 25 \mathrm{mg} / \mathrm{kgBB} \text {. }\end{array}$ \\
\hline $\mathrm{KGT}+\mathrm{D} 2+\mathrm{Te}$ & $\begin{array}{l}\text { Diletakkan dalam kandang gelap \& diberi pakan } \\
\text { tanpa vitamin D selama } 7 \text { hari }\end{array}$ & $\begin{array}{l}\text { Diletakkan kembali dalam kandang terang dan diberi pakan standar } \\
\text { serta diberi asupan vitamin D peroral sebanyak } 0,5 \mu \mathrm{g} / \mathrm{kgBB} / \mathrm{hari} \\
\text { selama } 4 \text { hari. Pada hari terakhir diberi tambahan teofilin } 25 \mathrm{mg} / \mathrm{BB} \text {. }\end{array}$ \\
\hline $\mathrm{KTT}+\mathrm{D} 1+\mathrm{Te}$ & $\begin{array}{l}\text { Diletakkan dalam kandang terang \& diberi } \\
\text { pakan standar selama } 7 \text { hari }\end{array}$ & $\begin{array}{l}\text { Tetap diletakkan dalam kandang terang \& diberi pakan standar } \\
\text { selama } 4 \text { hari serta di beri teofilin } 25 \mathrm{mg} / \mathrm{kgBB} \text { pada hari terakhir. }\end{array}$ \\
\hline
\end{tabular}

Keterangan:

KGG

KGG+Te

KGT+D1

$\mathrm{KGT}+\mathrm{D}_{1 / 2}+\mathrm{Te}$

$\mathrm{KGT}+\mathrm{D} 1+\mathrm{Te}$

$\mathrm{KGT}+\mathrm{D} 2+\mathrm{Te}$

$\mathrm{KTT}+\mathrm{D} 1+\mathrm{Te}$
Tetap diletakkan dalam kandang gelap \& diberi pakan tanpa

serta diberi asupan vitamin D peroral sebanyak $0,25 \mu \mathrm{g} / \mathrm{kgBB} /$ hari selama 4 hari serta diberi asupan vitamin D peroral sebanyak $0,125 \mu \mathrm{g} / \mathrm{kgBB} / \mathrm{hari}$ selama 4 hari. Pada hari terakhir diberi tambahan teofilin $25 \mathrm{mg} / \mathrm{BB}$.

Diletakkan kembali dalam kandang terang dan diberi pakan standar serta diberi asupan vitamin D peroral sebanyak 0,25 $\mathrm{\mu g} / \mathrm{kgBB} / \mathrm{har}$ Diletakkan kembali dalam kandang terang dan diberi pakan standar serta diberi asupan vitamin D peroral sebanyak $0,5 \mu \mathrm{g} / \mathrm{kgBB} / \mathrm{hari}$ selama 4 hari. Pada hari terakhir diberi tambahan teofilin $25 \mathrm{mg} / \mathrm{BB}$.

Tetap diletakkan dalam kandang terang \& diberi pakan standar
selama 4 hari serta di beri teofilin $25 \mathrm{mg} / \mathrm{kgBB}$ pada hari terakhir.

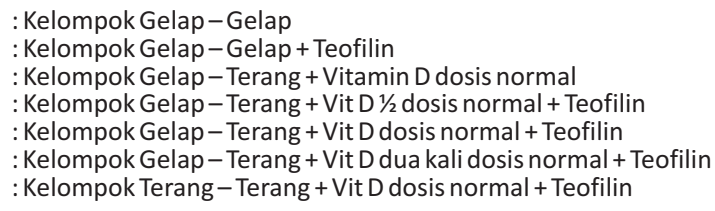




\section{HASIL}

Hasil penelitian pada tahap pertama terlihat pada Gambar 1, tampak adanya penurunan jumlah sel macula densa ginjal yang mengekspresikan COX-2 yang diikuti dengan penurunan TDS, penurunan keduanya makin tampak dengan penambahan dosis vitamin D yang diberikan.

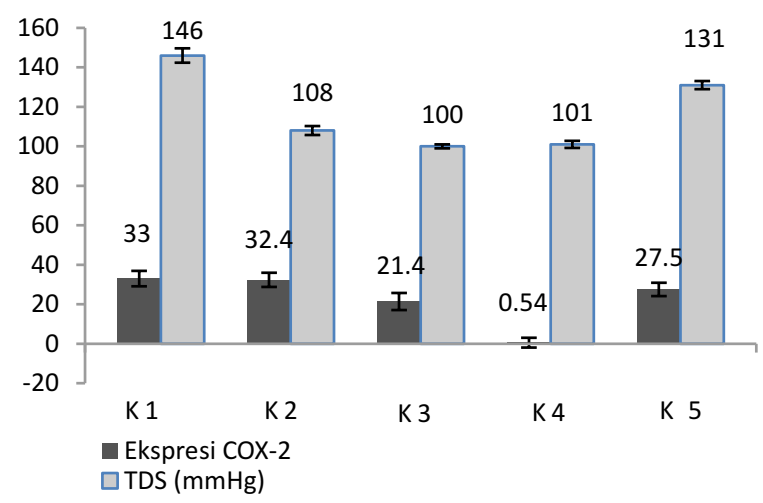

Gambar 1. Rata-rata ekspresi COX-2 dan TDS

Pada Gambar 1 tampak adanya kecenderungan penurunan ekspresi COX-2 di sel macula densa dengan bertambahnya dosis vitamin $D$ yang diberikan. Namun secara statistik, penurunan ekspresi COX-2 baru terlihat bermakna ( $p: 0,000)$ jika kita membandingkan antara K1 dengan $\mathrm{K} 4(0,54 \% \pm 2,50)$ dengan selisih ekspresi COX-2 sebesar $32,5 \%$. Hal ini menunjukkan bahwa perlu dosis besar vitamin D (2 kali dosis normal) untuk dapat menurunkan persentasi ekspresi COX-2 di sel macula densa ginjal. Sedangkan pada K5 $(27,5 \% \pm 3,4)$, kelompok kontrol positif yang terus berada di kandang gelap dan pada empat hari terakhir diberi penghambat COX-2, menunjukkan ada sedikit penurunan ekspresi COX-2 sebesar 5,5\% jika dibandingkan dengan K1, namun penurunannya juga tidak bermakna secara statistik ( $p$ : $0,365)$.
Pola gambar yang sama dengan ekspresi COX-2 juga tampak pada TDS. Pada gambar 1 tampak adanya penurunan TDS seiring dengan banyaknya dosis vitamin D yang diberikan. Bahkan pemberian vitamin $D$ setengah dosis normal (K2) sudah mampu menurunkan TDS secara bermakna. Namun penambahan dosis vitamin $D$ yang diberikan tidak mampu lagi menurunkan TDS, hal ini terlihat pada TDS K4 tidak berbeda bermakna dengan K3, sehingga dapat disimpulkan ada batas maksimal efek vitamin D dalam menurunkan TDS, jika efek itu telah tercapai, maka pemberian dosis vitamin D lebih besar lagi tidak akan mampu lagi menurunkan TDS.

Pola yang berbeda tampak pada $\mathrm{K} 5$, walaupun ada penurunan ekspresi COX-2 jika dibandingkan dengan K1, namum TDSnya justru tetap tinggi dan tidak berbeda bermakna jika dibandingkan dengan TDS pada K1. Hal ini menunjukkan bahwa pemberian indometasin $3 \mathrm{mg} / \mathrm{kg}$ $\mathrm{BB} /$ hari selama empat hari mampu menurunkan ekspresi COX-2 secara bermakna, tapi tidak mampu menurunkan tekanan darah sistolik (TDS) pada hewan coba.

Sedangkan hasil penelitian pada tahap kedua yang mempelajari pengaruh pemberian vitamin $D$ bersama dengan teofilin, tampak pada Gambar 2.

Jika dibandingkan KGG dengan KGG+Te terlihat peningkatan yang bermakna baik pada kadar CAMP, kadar renin darah dan TDS pada hewan coba (Gambar 2), hal ini menunjukkan adanya teofilin mampu mengakumulasi CAMP, sehingga kadar renin yang di produksi meningkat dan hasil akhirnya adalah adanya peningkatan TDS.

Jika dibandingkan KGG+Te dengan KGT+D1+Te terlihat adanya perbedaan yang signifikan, ada penurunan yang signifikan kadar CAMP, renin dan TDS pada kelompok yang diberi vitamin $D$ walaupun juga telah diberi teofilin, sehingga dapat disimpulkan bahwa pemberian teofilin bersama dengan vitamin $D$ tidak mampu mengakumulasi CAMP di sel macula densa ginjal, sehingga kadar CAMP turun, renin darah turun dan TDS tidak mengalami kenaikan. Semakin tinggi dosis vitamin D yang diberikan (dalam batas normal) akan makin menurunkan kadar CAMP sel ginjal, tapi tidak demikian dengan dosis 2 kali dari normal, karena jika kita membandingkan KGT+D1+Te

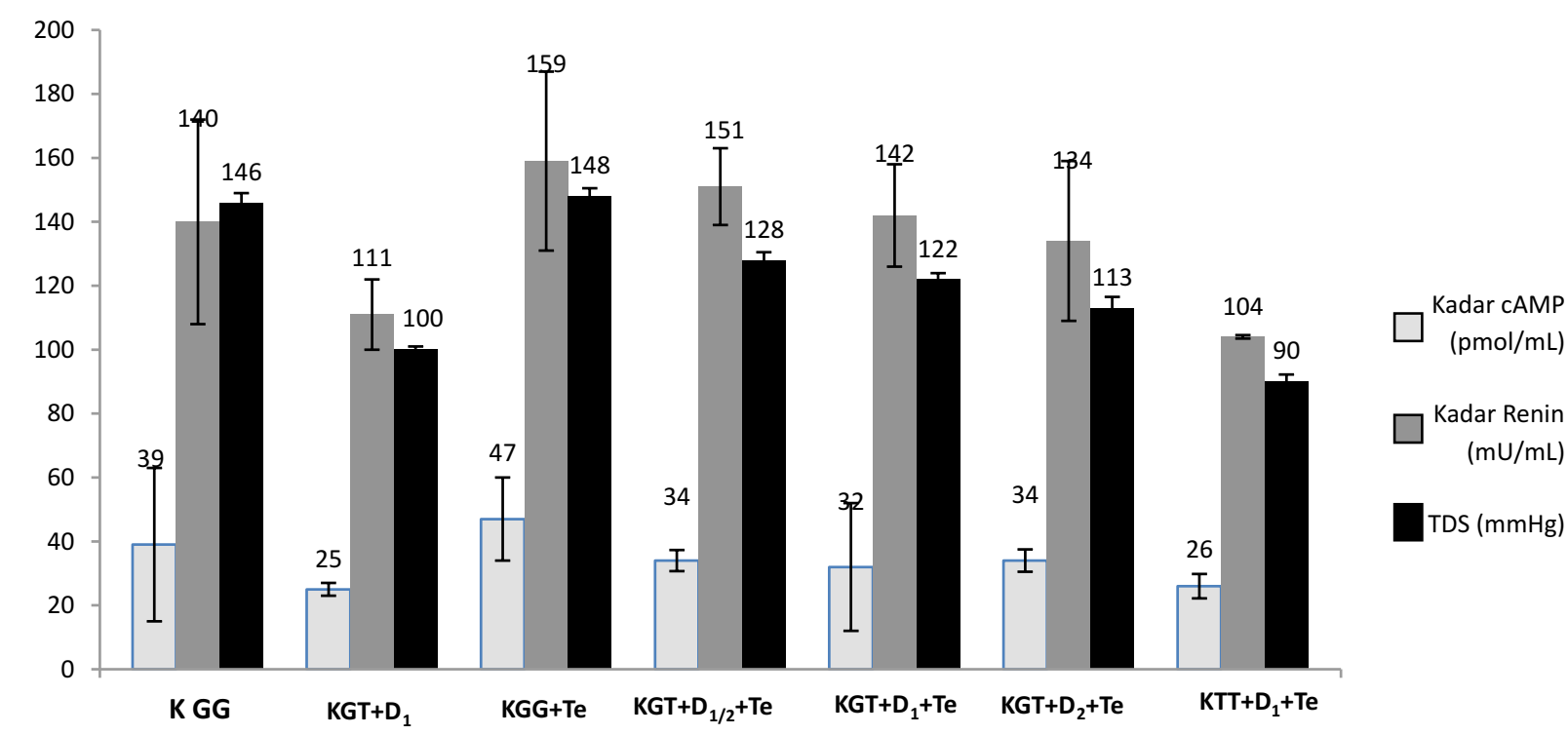

Gambar 2. Rata-rata cAMP, kadar renin dan TDS 
dengan KGT+D2+Te tidak menunjukkan adanya perbedaan yang signifikan, sehingga dapat disimpulkan peningkatan dosis vitamin $\mathrm{D}$ (dua kali dari dosis normal) yang diberikan tidak berpengaruh pada penurunan kadar CAMP, renin darah dan TDS.

Kadar cAMP sel ginjal paling rendah terdapat pada kelompok $\mathrm{KTT}+\mathrm{D} 1+\mathrm{Te}$, yaitu kelompok yang selama perlakuan ada di kandang terang dan diberi tambahan vitamin D dosis normal, walaupun sebenarnya kelompok ini juga diberi tambahan teofilin. Rendahnya kadar cAMP diikuti dengan rendahnya kadar renin darah dan TDS. Dari hasil ini menunjukkan bahwa kombinasi paparan sinar matahari dan pemberian vitamin $D$ peroral sangat baik dalam menurunkan kadar cAMP sel ginjal walaupun subjek penelitian telah diberi tambahan teofilin.

\section{DISKUSI}

Hasil menunjukkan bahwa ekspresi COX-2 di sel macula densa ginjal juga mampu dihambat dengan adanya vitamin $D$ mulai kelompok yang diberi dosis vitamin $D \frac{1}{2}$ dari normal, tapi perlu vitamin D dua kali dosis (K4) untuk menghambat ekspresi COX-2 secara bermakna ( $p: 0,000)$. Hal ini menunjukkan bahwa vitamin D memiliki sasaran aksi juga di bagian sebelum cAMP. Dugaan ini, didukung dengan data bahwa pemberian teofilin bersama dengan vitamin D pada kelompok KGT+D1+Te tidak mampu mengakumulasi cAMP, sehingga diduga tidak terjadinya akumulasi CAMP, karena tidak cukup bahan yang akan digunakan mengaktifkan Adenylate Cyclase (AC) serta untuk mengubah ATP menjadi cAMP akibat adanya penghambatan oleh vitamin D di COX-2 yang ada di bagian sebelum cAMP. COX-2 adalah enzim yang digunakan untuk mengubah asam arakidonat menjadi prostaglandin di sel macula densa. Prostaglandin di sel macula densa akan dikirim ke sel juxtaglomerular dan akan menyebabkan teraktivasinya adenilate siklase serta meningkatkan CAMP, sehingga hasil akhirnya adalah peningkatan produksi renin dan peningkatan tekanan darah (5,11-13).

COX-2 memegang peranan penting dalam pembentukan renin di ginjal, karena COX-2 yang akan mengubah asam arakidonat (AA) menjadi prostaglandin (PGE) di sel macula densa ginjal. Prostaglandin yang dibentuk di sel macula akan berinteraksi dengan reseptor PGE di sel juxtaglomerular sehingga akan mengaktifkan AC dan menyebabkan cAMP meningkat dan renin akan diproduksi. Peningkatan produksi renin yang berperan dalam aktifasi sistem renin angiotensin aldosteron, sehingga tekanan darah akan mengalami peningkatan.

Dari hasil (Gambar 1), tampak bahwa vitamin D mampu menghambat ekspresi COX-2 bahkan sejak $1 / 2$ dari dosis normal, ini menunjukkan bahwa peran vitamin $D$ tidak hanya di bagian sesudah cAMP dengan menghambat langsung transkripsi gen renin , tapi juga memiliki peran di bagian sebelum CAMP.

Hal ini sejalan dengan pendapat Krishnan \& Feldman (10) serta Swami dkk (14) yang melaporkan bahwa sasaran aksi vitamin $D$ pada pencegahan perkembangan sel kanker ada di bagian sebelum CAMP, yaitu dengan menurunkan ekspresi COX-2, menurunkan ekspresi reseptor prostaglandin dan meningkatkan kerja enzim 15 prostaglandin dehidrogenase (15-PDH). Pendapat ini juga didukung oleh Aparna, dkk (15), melaporkan bahwa vitamin D menekan produksi COX-2 pada sel kanker sehingga dapat menurunkan prostaglandin yang selanjutnya dapat mencegah proses perkembangan sel kanker.

Pada kelompok K1 yang selama penelitian berada di kandang gelap, menunjukkan ekspresi COX-2 (33\%) di sel makula densa. Ekspresi COX-2 meningkat pada keadaan gelap-gelap, paling tinggi jika dibandingkan dengan kelompok lainnya (Gambar 1). Hal ini menunjukkan bahwa rendahnya kadar vitamin $\mathrm{D}$ dalam darah menyebabkan ekspresi COX-2 di sel makula densa mengalami peningkatan. Kondisi ini menunjukkan bahwa tidak adanya vitamin D menyebabkan tidak ada yang menekan ekspresi COX-2, sehingga ekspresi COX-2 pada kelompok ini (K1) paling tinggi. Data ini menguatkan dugaan bahwa adanya vitamin $\mathrm{D}$ dalam darah menyebabkan ekspresi dari COX-2 terhambat. Akibatnya asam arakhidonat tidak dapat diubah menjadi prostaglandin. Hal ini sejalan dengan yang dilaporkan oleh Li (10) serta Swami dkk (14) hanya saja kajadian penghambatannya adalah di sel kanker, sedangkan dalam penelitian ini mekanisme penghambatan COX-2 oleh vitamin D terjadi di sel makula densa ginjal.

Hasil menunjukkan penurunan ekspresi COX-2 yang disebabkan oleh pemberian vitamin $D$ dua kali dosis pada K4 (0,54\%) bahkan terlihat lebih besar efeknya jika dibandingkan dengan kelompok yang diberi indometasin K5 $(27,5 \%)$, hal ini menunjukkan bahwa vitamin D memiliki efek penekanan pada ekspresi COX-2 di sel macula densa ginjal yang lebih kuat dibanding indometasin. Padahal indomethacine adalah bahan yang bersifat COX-2 inhibitor kuat, sehingga pemberian indomethacine diharapkan akan mampu menekan kerja dari COX-2. Kenyataan yang terjadi, mekanisme penghambatan ekspresi COX-2 antara vitamin D dan indomethacin, tampak lebih kuat mekanisme penghambatan COX-2 yang dilakukan oleh vitamin D. Pada kelompok yang diberi vitamin $\mathrm{D}$ dua kali dosis, tampak hampir tidak ada sel macula densa-nya yang masih mengekspresikan COX-2 (0,54\%), sedangkan pada kelompok yang diberi indomethacin, masih relatif banyak yaitu sebesar $27,5 \%$ sel macula densa masih menunjukan positif mengekspresikan COX-2. Hal serupa juga terlihat pada penurunan TDS, K5 yang diberi indometasin mengalami penurunan COX-2 dan penurunan TDS yang bermakna jika dibandingkan dengan K1.

Dari Gambar 2, menunjukkan bahwa pemberian teofilin bersama dengan vitamin $D$, tidak mampu mengakumulasi CAMP, sehingga renin tidak dibentuk dan TDS tidak mengalami kenaikan. Kondisi yang paling baik dalam menghambat akumulasi cAMP oleh teofilin ada pada kelompok KTT+D1+Te, yaitu kelompok hewan coba yang selama perlakuan mendapat vitamin $D$ baik dari oral ataupun paparan sinar matahari, sehingga dapat disimpulkan bahwa dua jalur sintesis vitamin $D$ berperan penting dalam menjaga kadar vitamin $D$ dalam darah dalam kondisi adekuat, sehingga mampu menstabilkan sistem renin angiotensin aldosteron. Hal ini sejalan dengan yang dilaporkan oleh Hermawan dkk (11) yang melihat adanya korelasi antara kadar vitamin D dalam darah dan TDS pada hewan coba, semakin rendah kadar vitamin D dalam darah maka makin tinggi TDS nya dan sebaliknya.

Untuk dapat memahami secara terinci tentang peran vitamin $\mathrm{D}$ dalam sistem renin angiotensin aldosteron 
dengan mempertimbangkan hasil penelitian terdahulu yang menunjukkan bahwa kerja vitamin $D$ ada di bagian sebelum cAMP $(4,5,9)$ dan melihat hasil penelitian ini yang menunjukkan bahwa vitamin $D$ juga memiliki sasaran kerja di bagian sebelum CAMP, yaitu dengan menghambat ekspresi COX-2 di sel macula densa ginjal, maka dapat digambarkan hasil mekanisme peran vitamin $\mathrm{D}$ dalam sistem renin angiotensin aldosteron seperti pada Gambar 3.

Secara terinci, hasil penelitian ini dapat terlihat pada Lampiran. Sasaran aksi vitamin D dalam sistem renin angiotensin-aldosteron tidak hanya pada penghambatan transkripsi renin saja (down-stream cAMP), tapi juga ada pada penghambatan ekspresi COX-2 di sel macula densa ginjal (di bagian up-stream cAMP). Jika ekspresi COX-2 di hambat, maka prostaglandin tidak terbentuk sehingga tidak ada yang mengaktifkan cAMP di sel juxtaglomerular. Jika cAMP tidak teraktivasi, maka proses selanjutnya tidak akan berjalan, dengan kata lain tidak akan ada renin yang dibentuk, sehingga sistem renin angiotensin-aldosteron tidak teraktivasi sehingga tekanan darah tidak akan mengalami peningkatan. Sesuai dengan pendapat Krishnan \& Feldman (10), penulis menduga, bahwa masih ada sasaran aksi vitamin D yang lain dalam sistem renin angiotensi aldosteron, yaitu diduga vitamin D mampu menghambat kerja reseptor prostaglandin dan mengaktifkan enzim 15-PDGH. Untuk itu diperlukan penelitian lebih lanjut untuk dapat menjawab dugaan

\section{DAFTAR PUSTAKA}

1. Ong KL, Cheung BM, Man YB, Lau CP, and Lam KS. Prevalence Awareness, Treatment, and Control of Hypertension among US Adults 1999-2004. Hypertension. 2007; 49(1): 69-75.

2. Ma J and Stafford RS. Screening, Treatment and Control of Hypertension in US Private Physician Officer 2003-2004. Hypertension. 2008; 51(5): 12751281.

3. Lilova M. Hypertension in Children with Chronic Renal Failure. The Turkish Journal of Pediatrics. 2005; 47: 28-31.

4. Li YC. Vitamin D Regulation of the Renin Angiotensin System: Mechanism and Implication. Journal of Cellular Biochemistry2003; 88(2): 327-331.

5. Yuan W, Pan W, Kong J, et al. 1,25-Dihydroxyvitamin D3 Suppresses Renin Gene Transcription by Blocking the Activity of the Cyclic AMP Response Element in the Renin Gene Promoter. Journal of Biological Chemistry. 2007; 282(41): 29821-29830.

6. Rostand SG. Ultraviolet Light May Contribute to Geographic and Racial Blood Pressure Differences. Hypertension. 1997; 30(2): 150-156.

7. Forman JP, Giovannucci E, Holmes MD, et al. Plasma 25-Hydroxyvitamin D Levels and Risk of Incident Hypertension. Hypertension. 2007; 49(5): 1063-1069.

8. Martini LA and Wood RJ. Vitamin D and Blood Pressure Connection: Update on Epidemiologic, Clinical, and Mechanistic Evidence. Nutrition tersebut

Dari hasil penelitian yang penulis lakukan dan mempertimbangkan pendapat Li (4) \& Yuan dkk (5) maka dapat disampaikan bahwa sasaran aksi vitamin $D$ pada sistem renin angiotensin-aldosteron kemungkinan ada di dua bagian, yaitu ada yang di bagian up-stream cAMP dengan menekan ekspresi COX-2 di sel macula densa ginjal (Gambar 1) dan ada yang dibagian down-stream cAMP, yaitu dengan menekan langsung gen yang menyandi berdasarkan hasil penelitian terdahulu $(4,5)$.

Vitamin D mampu menekan peningkatan kadar CAMP sel ginjal, kadar renin darah dan TDS walaupun hewan coba telah diberi tambahan teofilin, sehingga mendukung kesimpulan bahwa vitamin $D$ menghambat proses pembentukan renin jauh di bagian up stream cAMP. Kombinasi pemberian vitamin $D$ per-oral dan paparan sinar matahari sangat baik dalam menjaga TDS, kadar CAMP dan kadar renin dalam kondisi stabil, walaupun hewan coba telah diberi tambahan teofilin.

Untuk mendapatkan mekanisme kerja vitamin D pada sistem renin angiotensin-aldosteron yang jelas dan terinci, tentunya hasil penelitian ini masih memerlukan kajian lebih lanjut, untuk melihat apakah mekanisme hambatannya hanya di COX-2, atau juga ada di bagian lain, seperti di reseptor prostaglandin di sel juxtaglomerular ataupun di enzim 15-PDGH.

Reviews. 2008; 66(5): 291-297.

9. Li YC, Kong J, Wei M, Chen ZF, Liu SQ, and Cao LP. 1,25Dihydroxyvitamin $D(3)$ is a Negative Endocrine Regulator of the Renin-Angitensin System. The Journal of Clinical Investigation. 2002; 110(2): 229-238.

10. Krishnan AV and Feldman D. Molecular Pathway Mediating the Anti-Inflammatory Effect of Calcitriol: Implication for Prostate Cancer Chemoprevention and Treatment. Endocrine-related Cancer. 2010; 17(1): R19-R38.

11. Hermawan D, Kadarsih S, Sunarti, Astuti I, and Agus ZAN. Efek Asupan Vitamin D terhadap Tekanan Darah Sistolik Tikus Putih (Rattus norvegicus). Jurnal Gizi Klinik Indonesia. 2012; 9(1): 10-15.

12. Weng S, Sprague JE, Oh J, et al. Vitamin D Deficiency Induces High Blood Pressure and Accelerates Atherosclerosis in Mice. PLoS One. 2013; 8(1): es4625.

13. Harris RC. COX-2 and Kidney. Journal of Cardiovascular Pharmacology. 2006: 47: S37-S42.

14. Swami S, Krishnan AV, Moreno J, Bhattacharyya RB, Peehl DM, and Feldman D. Calcitriol and Genistein Action to Inhibit the Prostaglandin Pathway: Potential Combination Therapy to Treat Prostate Cancer. Journal of Nutrition. 2007; 137(1): 205S-210S.

15. Aparna $\mathrm{R}$, Subhashini J, Roy $\mathrm{KR}$, et al Selective Inhibition of Cyclooxygenase-2 (COX-2) by $1 \alpha$, 25Dihydroxy-16-ene-23-yne-Vitamin D3, a Less Calcemic Vitamin D Analog. Journal of Cellular Biochemistry. 2008; 104(5): 1832-1842. 
Lampiran

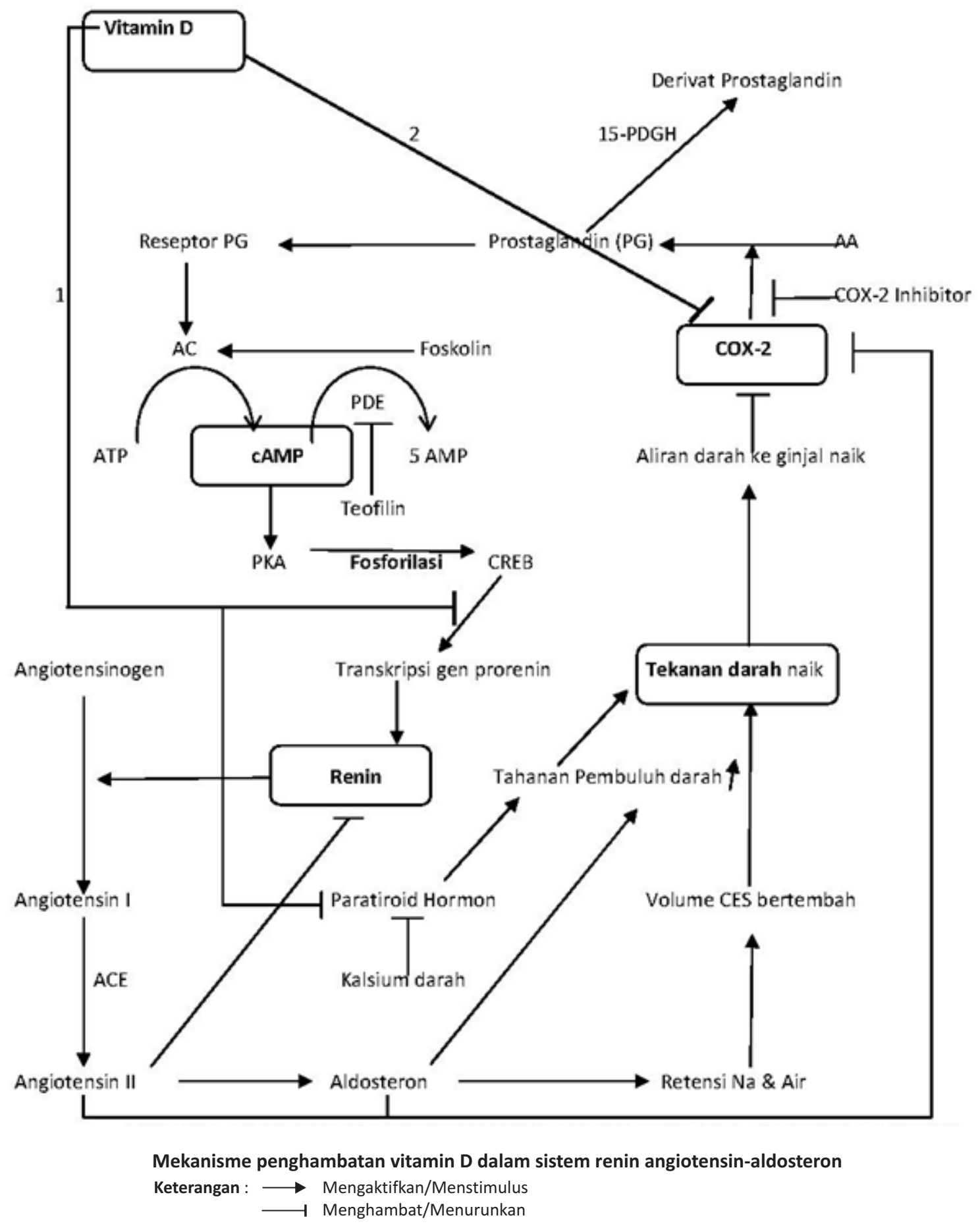

